\title{
Amastigota forms resembling Leishmania sp. on corneal ulceration in a dog: case report
}

\author{
[Formas amastigotas compativeis com Leishmania sp. em ulceração corneal de cão: relato de caso] \\ F.L.C. Brito ${ }^{1}$, L.C. Alves ${ }^{1}$, F.C.L. Maia ${ }^{1}$, A.R. Albuquerque ${ }^{1}$, J.P.D. Ortiz ${ }^{2}$, J.L. Laus $^{2}$ \\ ${ }^{1}$ Departamento de Medicina Veterinária, UFRPE - Recife, PE \\ ${ }^{2}$ Faculdade de Ciências Agrárias e Veterinárias - UNESP \\ Via de Acesso Prof. Paulo Donato Castellane, $\mathrm{s} / \mathrm{n}$ \\ 14884-900 - Jaboticabal, SP
}

\begin{abstract}
One dog with visceral leishmaniasis is reported presenting cutaneous lesions, cachexia, and corneal ulceration. Parasitological and serological diagnoses were performed by exam of contents of the aspirative punction of the bone marrow and by immunofluorecence, respectively. Amastigota forms resembling Leishmania sp. were visualized by citology.
\end{abstract}

Keywords: dog, ulceration corneal, Leishmania sp., ophthalmology

\section{RESUMO}

Relata-se o caso de um cão com leishmaniose visceral apresentando lesões cutâneas, caquexia e úlcera de córnea. Realizou-se o diagnóstico parasitológico e sorológico por meio de exame do material da medula óssea e por imunofluorescência indireta, respectivamente. À citologia da úlcera corneana, visibilizaram-se formas amastigotas compativeis com Leishmania sp.

Palavras-chave: cão, úlcera de córnea, Leishmania sp., oftalmologia

\section{INTRODUCTION}

In Brazil, canine visceral leishmaniasis is also known as canine calazar and it is a potentially lethal zoonosis caused by a protozooan, a macrophages intracellular parasite from the Leishmania (Leishmania) chagasi species (Feitosa et al., 2000).

Dogs affected by visceral leishmaniasis usually develop the systemic form of the disease showing a great range of clinical signs (Noli, 1999). Ocular manifestations have been described in canine leishmaniasis affecting over $50 \%$ of the infected animals (Brito et al., 2006). Canine calazar affects mostly the anterior segment of the eye (Puchol ad Gonzalez, 1989).

Corneal limited involvement is seldom observed. Keratitis associated to conjunctival and uveal

Recebido em 23 de outubro de 2004

Aceito em 20 de setembro de 2006

E-mail: fabiobrito@click21.com.br inflammation is often observed (Roze, 1986). Nevertheless, corneal exclusively pathologies, such as superficial and stromal keratitis and descementocele may be observed in dogs with canine calazar (Molleda et al., 1993; Roze, 2002).

There are a great number of studies about canine leishmaniasis pathogeny and lesions, although very few reported in detail the ocular lesions due to this disease (Garcia-Alonso et al., 1998).

\section{CASE REPORT}

A seven year-old German shepherd male dog was referred to the veterinary hospital at the Universidade Federal Rural de Pernambuco, Brazil, with clinical suspicion of canine visceral leishmaniasis. At clinical examination, cachexia and cutaneous lesions were observed. Ophthalmic examination revealed photophobia, blepharospasm, 
neovascularization and discrete corneal edema. Erosion of the corneal epithelium was observed in the right eye. The corneal ulceration was confirmed after the fluorescein test (Fig. 1). Anterior chamber, uveal tract, lens, vitreo and retina were normal in both eyes. Following the diagnosis, treatment was performed using antibiotic therapy (Tobramicina ${ }^{\circledR}$ eye drops ${ }^{1}$ ) at regular intervals of 6 hours for 15 days and condroitin sulfato (Dunason ${ }^{\circledR}$ eye drops ${ }^{1}$ ) at regular intervals of 8 hours over the same period. No improvement was observed following this medical treatment which demanded a revaluation. Since the animal came from an endemic region, cytology of the wounded area was performed. Anesthetic eye drops (Anestalcon ${ }^{\circledR}$ eye drops ${ }^{1}$ ) was instilled previously the cytology. Soon after, the cytology of the corneal area was proceeded avoiding the contact with the conjunctive. The material obtained from the ulcer was stained by the fast staining technique and evaluated using an optic microscopy at a $1000 \mathrm{x}$ magnification. The analyses demonstrated the presence of epithelial cells, polimorphonuclears, red blood cells and also structures resembling amastigota forms of Leishmania sp. (Fig. 2 and 3). Meanwhile, it was performed the aspiration of the bone marrow in which amastigota forms of Leishmania sp. were observed. Indirect immunofluorescence was also performed and a seropositive reaction was observed in a 1:640 titer.

\section{DISCUSSION}

Canine visceral leishmaniasis is a chronic disease associated with varied clinical signs. Due to the diversity of clinical presentation; the disease may be difficult to diagnosis. Ocular alterations have been reported in some studies, as being common in dogs infected by Leishmania infantum and $L$. chagasi, such as uveitis and conjunctivitis (Peña et al., 2000; Brito et al., 2006). The ophthalmic form of this disease involving the cornea is less frequent, unless other ocular structures be involved (Roze, 2002).

Despite the very few reports and the low frequency in which isolated corneal involvement occurs in animals affected by visceral leishmaniasis, similar lesions to those reported by this study were described in dogs with ocular disease secondary to leishmaniasis (Roze, 1986). Deep corneal ulceration was reported in dogs and in one cat affected by visceral leishmaniasis (Roze, 2002; Leiva et al., 2002).

Ophthalmic reevaluation and corneal ulcer cytology in this case were due to the lack of success on previous treatment, since uncomplicated superficial clinical ulcers normally heal in a few days (Whitley and Gilger, 2003).

Corneal ulceration can be related to various factors. Fungi, bacteria and parasites may also induce corneal enzymatic degradation. Normally lesions get worse due to neutrophils quimiotatic action, which release lithic enzymes as they degranulate in the stroma (Gordon et al., 1980).

The mechanism which explains the presence of amastigota forms of Leishmania sp. in ocular tissues is unknown (Garcia-Alonso et al., 1996), although some admit that the parasites are carried to the cornea by antigen presenting cells (Saint-André Marchal et al., 1997). The main mononuclear cell population present at the ocular surfaces is represented by the Langerhans cells, especially at the conjuntival and corneal tissues (Wu and Zhang, 1991; Bielory, 2000). These cells have an important role at the ocular surface immunity (Gillette et al., 1982). Because macrophages, dendritic cells and Langerhans cells are the main APCs over Leishmaniasis (Ferrer et al., 1988), it is easy to understand the involvement of the immunogenic mechanisms on the ocular surface in events of CVL.

Antigenic stimulation and lymphocyte $\mathrm{T}$ migration leads to local antibodies production which probably achieve the cornea by diffusion. Presence of activated T lymphocyte at the cornea acts on antibody production by the secretion of the B cells growing factor. At the same time plasmocytes unchain an increase on total immunoglobulin levels. Therefore, in canine visceral leishmaniasis the response to immunoglobulins is significatively high, being deleterious instead of protective, permitting clinical signs to appear (Abbas et al., 1995; Noli, 1999). It is admitted that the lesion of the corneal epithelium in this case is connected to immune mediated events.

${ }^{1}$ Alcon - São Paulo, Brazil 


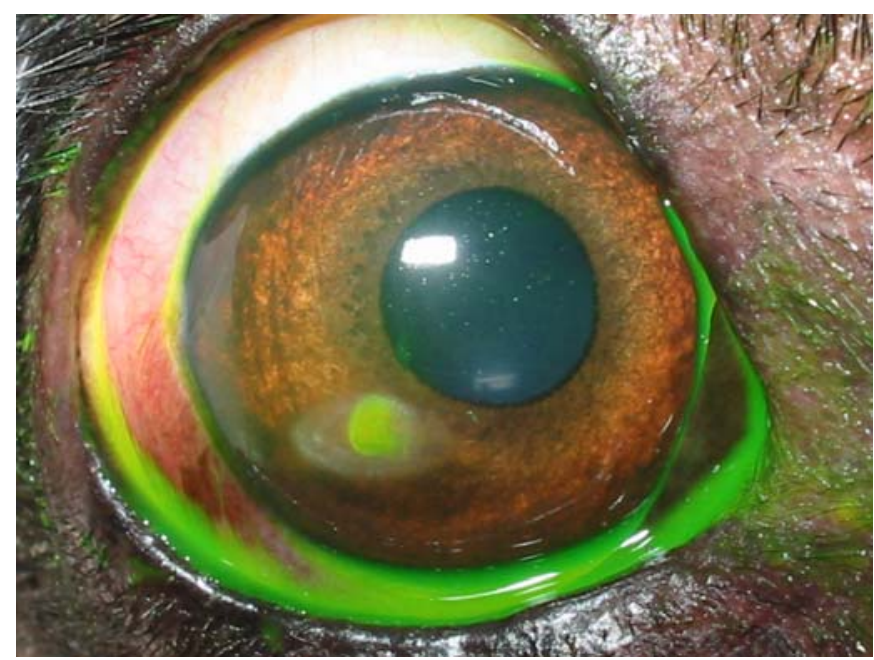

Figure 1. Superficial ulcerative keratitis in a dog naturally infected by Leishmania (Leishmania) chagasi: corneal edema with erosion of the epithelium and superficial stroma stained by fluorescein.

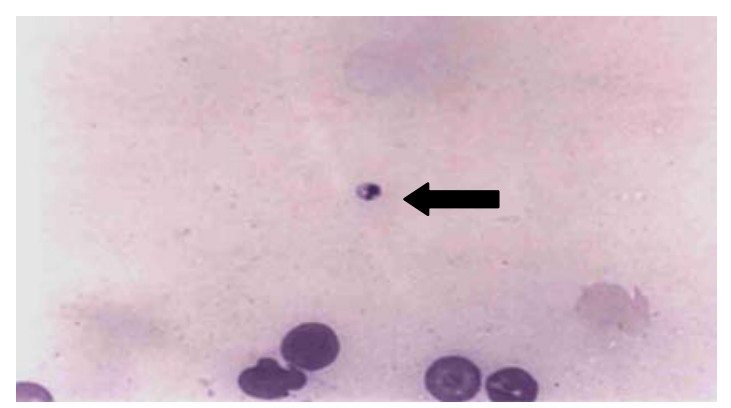

Figure 2. Photomicrography obtained by the cytology of the cornea ulceration: the presence of structures resembling amastigota forms of Leishmania sp. Fast staining 1000x.

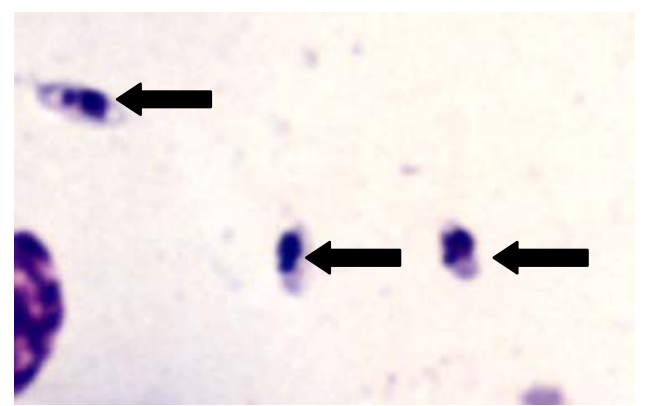

Figure 3. Photomicrography obtained by the cytology of the corneal ulceration: the presence of structures resembling amastigota forms of Leishmania sp. Fast staining 1400x.
In similar corneal ulceration in stromal keratitis caused by type 1 simple herpesvirus it is proposed that the response be mediated by virusspecific $\mathrm{T}$ limphocytes of the delayed hypersensibility type promoted by the Langerhans cells just like the immunogenic responses unchained by visceral leishmaniasis (McLeish et al., 1989).

The presence of Leishmania has been described in the conjunctival ocular of dogs naturally infected (Laugier and Verro-Baoulanger, 1992). Therefore, the care should be taken in the procedure of the corneal cytology, for also not raising lesion of the conjunctive and, consequently, contamination of the material by conjunctival cells.

The literature consulted did not report studies showing the amastigota forms of Leishmania sp. at corneal cytology, except when from the nodules at cornea or limbus. Therefore, this is the first case that the authors describe the superficial ulcerative keratitis in which structures resembling amastigota forms of Leishmania $\mathrm{sp}$. are isolated from the wounded area. 


\section{CONCLUSIONS}

It is important to highlight that the ophthalmic signs in dogs are being correlated to visceral leishmaniasis, especially at the anterior segment of the eye. Therefore, in endemic areas where corneal affections non responsive to the conventional treatment is present, canine visceral leishmaniasis with ocular manifestations must be considered as a differential diagnosis. In the future, studies including a larger number of animals are necessary to elucidate the presence of the parasite in the area of the lesion.

\section{REFERENCES}

ABBAS, A.K.; LICHTMAN, A.H.; POBER, J.S. Imunidade aos Micróbios. In: Imunologia celular e molecular. Rio de Janeiro: Revinter, 1995. p.329-334.

BIELORY, L. Allergic and immunologic disorders of the eye. Part I: Immunology of the eye. J. Allergy Clin. Immunol., v.5, p.805-816, 2000.

BRITO, F.L.C. Alterações oculares e análise do humor aquoso de cães (Canis familiaris LINNEUS, 1758). 2004. 53f. Dissertação (Mestrado em Ciência Veterinária) - Universidade Federal Rural de Pernambuco, Recife.

BRITO, F.L.C.; ALVES, L.C.; MAIA, F.C.L. et al. Ocular alterations in dogs naturally infected by Leishmania (Leishmania) chagasi. Arq. Bras. Med. Vet. Zootec., v.58, p.768-775, 2006.

FEITOSA, M. M.; IKEDA, F. A.; LUVIZOTTO, M. C. et al. Aspectos clínicos de cães com leishmaniose visceral no município de Araçatuba - São Paulo (Brasil). Clín. Vet., v.28, p.36-42, 2000.

FERRER, L.; RABANAL, R.; FONDEVILA, D. et al. Skin lesions in canine leishmaniasis. J. Small Anim. Pract., v.29, p.381-388, 1988.

GARCIA-ALONSO, M.; BLANCO, A.; RINA, D. et al. Immunopathology of the uveitis in canine leishmaniasis. Parasite Immunol., v.18, p.617-623, 1996.

GARCIA-ALONSO, M.; MIRÓN, C.; MOLANO, I. et al. Patología ocular asociada a leishmaniosis canina. Cons. Dif. Vet., v.54, p.49-53, 1998.

GILLETTE, T.E.; CHANDLER, J.W.; GEINER, J.V. Langerhans cell of the ocular surface. Ophthalmology, v.89, p. 700-711, 1982 .
GORDON, J.M.; BAUER, E.A.; EISEN, A.Z. Collagenase in human cornea: immunologic localization. Arch. Ophthalmol., v.2, p.341-345, 1980.

LAUGIER, C.; VERRO-BOULANGER, C. Ocular leishmaniasis. Prat. Med. Chir. Anim. Comp., v.27, p.751-752, 1992.

LEIVA, M.; LLORET, A.; PEÑA, T. et al. Ocular and visceral leishmaniosis in a domestic cat. Vet. Ophthalmol., v.5, p.285, 2002. (Abstract).

MCLEISH, W.; RUBSAMEN, P.; ATHERTON, S.S. et al. Immunobiology of Langerhans cells on the ocular surface. II Role of central corneal Langerhans cells in stromal keratitis following experimental HSV1 infection in mice. Reg. Immunol., v.4, p.136-143, 1989.

MOLLEDA, J.M.; NOVALES, M.; GINEL, P.J., et al. Clinical and histopathological study of the eye in canine leishmaniasis. Israel J. Vet. Med., v.48, p.173178,1993

NOLI, C. Canine leishmaniasis. Waltham Focus, n.2, p.16-24, 1999

PEÑA, M.T.; ROURA, X.; DAVIDSON, M.G. Ocular and periocular manifestations of leishmaniasis in dog: 105 cases (1993-1998). Vet. Ophthalmol., v.3, p.3541, 2000.

PUCHOL, J.L.; GONZALEZ, J.L. Leishmaniasis ocular: afeciones del segmento anterior. In: NATIONAL CONGRESS OF AVEPA, 24., 1989, Barcelona. Proceedings...Barcelona: AVEPA, 1989. p.115-122.

ROZE, M. Manifestations oculaires de la leishmaniose canine. Rec. Med. Vet., v.162, p.19-26, 1986.

ROZE, M. Ocular manifestation of canine lesihmaniasis. Diagnosis and treatment. In: WORLD SMALL ANIMAL VETERINARY CONGRESS, 27. 2002, Granada. Proceedings... Granada: WSAVA, 2002 .

SAINT-ANDRÉ MARCHAL， I.; MARCHAL, T.; MOORE, P.F. et al. Infection of canine Langerhans cells and interdigitating dendritic cells by Leishmania infantum in spontaneous canine leishmaniasis. Rev. Med. Vet., v.148, p.29-36, 1997.

WHITLEY, R.D.; GILGER, B. C. Doenças e cirurgia da córnea e esclera. In: GELATT, K. N. (Ed). Manual de oftalmologia veterinária. São Paulo: Manole, 2003. p.125-164.

WU, H.; ZHANG, L. The effect of suturing on Langerhans cells of the ocular surface. Zhonghua Yan Ke Za Zhi, v.6, p.361-363, 1991. 